\title{
COORDINATES OF THE CREDIT INSTITUTION ACTIVITY
}

\author{
M. R. Ţîrlea
}

\author{
Mariana Rodica Ţîrlea \\ Faculty of Economic Sciences Cluj-Napoca, \\ "Dimitrie Cantemir" Christian University Bucharest, Cluj-Napoca, Romania \\ *Correspondence: Mariana Rodica Țîrlea, 56 Teodor Mihali St., 400591, Cluj-Napoca, Cluj, \\ Romania \\ E-mail: rodica.tirlea@cantemircluj.ro
}

\begin{abstract}
The Emergency Ordinance no. 99 of 6 December 2006, on credit institutions and capital adequacy, presents the credit institution as "an entity whose business is to attract deposits or other repayable funds from the public and to grant credits in its own account". The 2006/48/EC Directive of the European Parliament and the European Council, presents the credit institution as "an undertaking whose business is to receive deposits and other repayable funds from the public and to grant credits for its own account" definition that seems appropriate, justified by the fact that, in our opinion, the concept of undertaking is assigned to those innovative and imaginative companies that produce goods. Since money is a commodity and economic agents that we call credit institutions produce money by reinventing themselves every day to keep up with technology, we consider that the idea of "undertaking" formulated by the 2006/48/EC Directive of the European Parliament and of the European Council is appropriate and that these credit institutions be hereinafter referred to as undertakings and therefore enterprises. We believe that the enterprise, in our case, the credit institutions, is a matter that produces, consumes and trades services in order to achieve positive economic effects therefore saving and lending are their direct support. Moreover, credit is the source for financing growth and welfare, therefore the engine of the capitalist economy.
\end{abstract}

Keywords: credit institution, specific conditions, authorization, general conditions, credit, savings, undertaking, enterprise

\section{Introduction}

\section{Coordinates of the "credit institution" theoretical concept}

In light of the Emergency Ordinance no. 99 of 6 December 2006, On credit institutions and capital adequacy, published in the Official Gazette no. 1027 of 27 December 2006, article 3 , paragraph (1), clause 10, the credit institution is presented as "an entity whose business is to attract deposits or other repayable funds from the public and to grant credits in its own account".

In the understanding of the Emergency Ordinance, by public, one should understand "any natural person, legal person or entity with no legal personality, that doesn't have the necessary knowledge and experience to assess the default risk of an investment. The items that do not fall into this category are: the state, central, regional and local public administration authorities, government agencies, central banks, credit institutions, financial institutions and other institutions" 1 .

The 2006/48/EC Directive of the European Parliament and the European Council, defines the credit institution as "an undertaking whose business is to receive deposits and other

\footnotetext{
${ }^{1}$ Emergency Ordinance no. 99 from the $6^{\text {th }}$ of December 2006, On credit institutions and capital adequacy, published in the Official Gazette no. 1027 of the $27^{\text {th }}$ of December 2006.
} 
repayable funds from the public and to grant credits in its own account" ${ }^{2}$, definition that seems appropriate.

Starting from this definition, given by the European Parliament and the European Council, the enterprise does not work in isolation; it operates in a complex system that, on a commercial background, produces goods and offers services. The enterprise's functionality within the system, is given by its specific organization on several activity fields, management fields and according to the fields of the patrimony's economic and financial management, organization which is always unique and personal. The company's uniqueness is guaranteed from the moment it is registred as a legal entity, when it is assigned with a unique registration code by the National Trade Register Office and a VAT number by the Department of Public Finance and the organization style, the management and administration style, is specific to each company.

Regardless its legal, economical or decisional existence, its form of organization, the industy it belongs to or the nature and form of the capital use, the company operates in a highly complex nature of material and financial flows. These material and financial flows are finding themselves in a mutual interdependence and conditionality, determined on one hand by its own organizational and operational system, therefore issues related to the company's internal environment, but also by the influence of the company's external environment: legal, economical and social, on the other hand.

\section{Specific operational conditions in credit institutions}

The way credit institutions are built and the way they operate is determined by the Emergency Ordinance no. 99 of 6 December 2006, on credit institutions and capital adequacy, published in the Official Gazette no. 1027 of 27 December 2006, which regulates specific conditions on the access and performance of the banking activity in Romania, which "pursues the following aspects:

$>$ the prudential supervision of credit institutions and companies providing investment services;

$>$ monitoring and supervising payment systems;

$>$ tracking and supervising the financial instrument operations settlement systems". ${ }^{3}$

As an application field, the ordinance is aimed at:

$>$ Romanian legal entities;

$>$ credit institutions;

$>$ foreign branches of national legal entities;

$>$ companies offering investment services;

$>$ member state credit institutions operating in Romania;

$>$ investment management companies;

$>$ companies managing individual investment portfolios.

Credit institutions activity, according to the Emergency Ordinance number 99/2006 implies and conditions, the cumulative existence of two types of activities:

1. attractic deposits or other repayable funds from the public;

2. granting loans.

With regard to the activity of an authorized credit institution, it's important to mention that "only activities with a substantiated activity plan will be authorized. Also, they must meet the general and specific requirements, whenever they exist, on conducting their activity under the applicable legal conditions." ${ }^{4}$

\footnotetext{
${ }^{2}$ The 2006/48/CE Directive of the Parliament and the European Council

${ }^{3}$ The Emergency Ordinance no. 99 from the $6^{\text {th }}$ of December 2006, On credit institutions and capital adequacy, published in the Official Gazette no. 1027, from 27th of December 2006.

${ }^{4}$ The National Bank of Romania, Reglementation no. 11/2007

${ }^{4}$ The Emergency Ordinance no. 99 from the $6^{\text {th }}$ of December 2006, On credit institutions and capital adequacy, published in the Official Gazette no. 1027, from 27th of December 2006.
} 
As a result, the National Bank of Romania imposes specific conditions for credit institutions that want to receive the authorization to operate. These specific conditions refer to satisfying the minimum criteria, reffered to by the Emergency Ordinance no. 99 of 6th December 2006, on credit institutions and capital adequacy, according to which "the credit institution:

$>$ has its own funds;

$>$ the level of the initial capital, must be at least equal to the minimum level established by regulations but it cannot be less than the equivalent of 5 million euros;

$>$ the initial capital, when a credit institution is establishment, is the registered capital, except for situations when the credit institution is the result of a merger or division reorganization process;

$>$ when a company is created, the registered capital must be fully paid in cash upon subscription;

$>$ any increase in capital must be fully paid in cash;

$>$ when establishment a credit institution, contributions in kind are not allowed;

$>$ the shares belonging to a credit institution can only be nominative;

$>$ credit institutions that are Romanian legal entities, don't have the right to establish exceptions to the principle that a share entitles to only one vote;

$>$ the capital contributions to the establishment of a credit institution, will be paid into a blocked account, opened with a credit institution, until the credit institution is registered as a Romanian legal entity in the Trade Register Office;

$>$ the activity's operational management must be provided by at least two people;

$>$ the people assigned as the management of a credit institution, shall have adequate reputation and experience in order to exercise their responsibilities;

$>$ the credit institution's registered office, Romanian legal person or its real head office must be located in Romania;

$>$ the Romanian credit institution must, conduct the business it was authorized for, effectively and mostly in Romania;

$>$ in order to give its authorization for a credit institution, the National Bank of Romania shall be informed of:

- the identities of the shareholders or members, whether natural or legal, that are due to hold a direct or indirect ownership interest in the credit institution;

- the value of those holdings;

- ensure a sound and prudent management of the credit institution;

- ensure the quality of the people who will manage the credit institution;

- if there are close links between the credit institution, Romanian legal entity, and other natural or legal persons, the National Bank of Romania shall grant authorization only if those links do not prevent the effective exercise of its supervisory functions. following:

In determining a qualifying ownership interest one shall take into account the

a) voting rights held by others on behalf of that person;

b) voting rights held by an entity controlled by that person;

c) voting rights held by a third party based on a contract or written agreement, which compels him to act in concertedly;

d) voting rights held by a third party based on a written agreement with that person or an entity under its control, which provides temporary transfer of voting rights to third parties, in exchange for a counterperformance;

e) the voting rights attached to the shares given as collateral by the person; except the situation when the person in whose favor the shares were pledged holds the voting rights and declares its intention of exercising them, in which case the voting rights be considered as belonging to the person in whose favor the shares were pledged;

f) voting rights attached to shares that come with an usufruct right for the beneficiary; 
g) voting rights which that person or one of the other persons or entities mentioned in the a) f) letters is entitled to acquire the on its own initiative, under a formal agreement;

h) voting rights attached to shares deposited with a person, that may be discretionary exercised, in the absence of specific instructions from the holders of these shares."

The National Bank of Romania requires for any authorization application to be accompanied by a business plan. This business plan should include:

- the organizational structure of the credit institution;

- the types of activities it intends to organize;

- solutions to its ability of achieving the proposed objectives, consistent with the rules and regulations of a prudent and sound banking practice;

- solutions for the adequacy of the management framework;

- the existence of internal procedures for the capital mechanism and structure, adapted to the activity's specific and complexity, but also to the volume of transactions that it intends to undertake.

If credit institutions wish so, they can also organize other activities, in addition to the core business, as long as they comply with the regulations imposed by the National Bank of Romania.

In Romania, the National Bank of Romania is the authority that provides the legal framework that regulates, authorizes and ensures prudential supervision of credit institutions.

The National Bank of Romania imposes mandatory conditions for obtaining the functioning authorization, issues clarifications related to the documentation that must accompany approval application and notifies the European Commission about the conditions under which authorization may be granted.

Article 5 of the 99/2006 Ordinance, states that: "Any natural person or legal entity without legal personality, which is not a credit institution, is forbidden to engage in any activity meant for attracting deposits or other reimbursable funds from the public, in any activity involving the issuing of electronic money or in the business of raising and / or managing money from the contributions of members of a group of people especially created to acquire collective funds and then grant loans / borrowings of these accumulated funds, for the purchase of goods and / or services by the group's members" 6 .

This prohibition is generally available excepting a few circumstances when different institutions that can take deposits or other repayable funds:

a) member states, regional governments or local authorities of a member state;

b) public international bodies, one or more of which is a member states;

c) in cases specifically stipulated by the Romanian legislation, the national law of another member state or the community's legislation, provided that these activities are properly regulated and supervised in order to protect depositors and investors.

(3) In applying the provisions of paragraph (1) and (2) a bond issue or other similar financial instruments is considered attraction of funds from the public if at least one of the following conditions is met:

a) it is the issuer's sole or main activity;

b) the issuer conducts a professional lending activity, or one or more of the activities referred to in article 18 paragraph (1) letter c)-1). ${ }^{7}$

The National Bank of Romania is the only bank authorized to appreciate whether an activity is or not deposit drawing according to Ordinance No. 99/2006 or other repayable funds from the public.

\footnotetext{
${ }^{5}$ The Emergency Ordinance no. 99 from the $6^{\text {th }}$ of December 2006, On credit institutions and capital adequacy, published in the Official Gazette no. 1027, from 27th of December 2006.

${ }^{6}$ The Emergency Ordinance no. 99 from the $6^{\text {th }}$ of December 2006, On credit institutions and capital adequacy, published in the Official Gazette no. 1027, from 27th of December 2006.

${ }^{7}$ Idem.
} 
Article 6 paragraph (1) of the ordinance "prohibits any person, other than an authorized credit institution, to use the name "bank" or "credit cooperative organization", "credit cooperative", "central credit union", "cooperative bank", "central cooperative bank", "mortgage bank", "bank for association savings and loans", "electronic money institution" or derivatives or translations of these names, in relation to an activity, a product or service unless such use is established or recognized by law or an international agreement, or when the context in which that name is used, visibly shows that banking activity is not being pursued." 8 .

Dismemberments of a credit institution (branches, agencies, subsidiaries, operational branches) in Romania may use in their name, according to the 99/2006 Ordinance, the name or other identification elements of their parent company, its initials, logo or emblem.

\section{Common conditions for the establishment and operation of credit institutions}

In Romania, credit institutions must operate only as stock companies. The current legislative regulations on the establishment and functioning of banks are based on:

$>$ Law no. 31/1990, Commercial company law - common Law;

$>$ Articles of the company's memorandum of association;

$>$ Law no. 58, Banking Law - specific law;

$>$ Government Emergency Ordinance no. 99/2006, which supplements and amends Law no. 58 - specific law;

$>$ The authorization issued by the National Bank of Romania.

The National Bank of Romania grants authorization to credit institutions only if it is convinced that they can carry activities safely, in compliance with sound and prudent management criteria, in such a way as to protect the interests of clients, respecting the Government Emergency Ordinance no. 99/2006 and the regulations issued for its implementation.

When considering a credit institution for authorization, the National Bank of Romania will consider the following: name of the credit institution, its activity, people ensuring the administration and / or the management, shareholders, financial auditor.

Establishing a credit institution involves two stages, resulting in:

under common law, establishment formalities and the credit institution's approval by the National Bank of Romania, must be met;

$>$ authorization of the company's banking activity by the National Bank of Romania.

Legal provisions state that the authorization of banks by the Central Bank of Romania involves two stages ${ }^{9}$ : approval of the banking company in accordance to Law no. 31/1990 on commercial companies and the Government Emergency Ordinance no. 99/2006, authorizing the bank's activity.

The method for establishing credit institutions is unique in accordance with the requirements of Law 31/1990, in compliance with the minimum level of the registered capital, namely "separate owned funds or an initial capital that cannot be less than the equivalent in lei of 5 million euros"10 and conditions regarding the shareholders.

Article 32, paragraph 2 of the Ordinance 99/2006, comes with a prohibition, in the sense that any credit institution "cannot be established by public subscription". ${ }^{11}$

After receiving the approval statement by the Central Bank of Romania, within two months, the credit institution must submit to the National Bank of Romania "the documents certifying the legal establishment, according to the applicable provisions in order to obtain the operating authorization ${ }^{12}$.

\footnotetext{
${ }^{8}$ Idem.

${ }^{9}$ Article 3 paragraph (1) of the National Bank's reglementation no. 11/2007.

${ }^{10}$ Article 25 paragraph 1 of the Gouverment Emergency Ordinance no. 99/2006.

${ }^{11}$ Article 21 in Law no. 31/1990 publiched in the Official Gazette of Romania, Part I, no. 126-127 from the $17^{\text {th }}$ of November 1990.

${ }^{12}$ Article 33, paragraph 5 of the Gouverment Emergency Ordinance no. 99/2006.
} 
Then the credit institution's registration in the Trade Register Office takes place, followed by doing the inventory and the publicity.

Establishing a credit institution, a Romanian legal entity, assumes that it has its own funds, which may not be less in value than the equivalent in lei of 5 million euros, fully paid upon subscription in cash, situation which is also valid if the capital increases. The contributions to the initial capital are paid into an account previously opened at a credit institution, the account remaining locked until the credit institution is registration with the Trade Register Office.

The shares can only be nominative, with no exceptions to the principle: one share entitles to one vote.

The registered office or the head office of the credit institution, recorded as a Romanian legal entity must be located in Romania.

The management of a credit institution has the possibility to opt for a unitary management system, according to article $137-152$ of law no. $31 / 1990$ or for the dual administration system according to article $153-153$ of the law no. 31/1990.

On the territory of a third country, credit institutions can perform the activities authorized by the National Bank of Romania "only by establishing a branch"13 and making it subject to the prior approval of the Central Bank

The establishment of credit institutions is based on common law no. 31/1990 of the commercial companies and the provisions of the specific law Government Emergency Ordinance no. 99/2006, concerning the authorization and operation of credit institutions.

\section{institutions}

4. The legal framework for the establishment and operation of banking

Regulations underlying the establishment and operation of credit institutions are:

Law no. 31/1990, the commercial companies' law;

Law no. 58, banking law - specific law;

Gouvernment Emergency Ordinance no. 99/2006, supplementing and amending law no. 58;

$>$ The authorization issued by the National Bank of Romania.

The National Bank of Romania grants authorization to credit institutions only if it is convinced that they can carry activities safely, in compliance with sound and prudent management criteria, in such a way as to protect the interests of clients, respecting the Government Emergency Ordinance no. 99/2006 and the regulations issued for its implementation.

When considering a credit institution for authorization, the National Bank of Romania will consider the following: name of the credit institution, its activity, people ensuring the administration and / or the management, shareholders, financial auditor.

Establishing a credit institution involves two stages:

$>$ receiving approval from the National Bank of Romania;

$>$ authorization of the company's activity by the National Bank of Romania.

The credit institutions' authorization process by the Central Bank of Romania involves two stages ${ }^{14}$ : "approval of the credit institution's establishment in accordance to law no. 31/1990 on commercial companies and the Government Emergency Ordinance no. 99/2006, authorizing the bank's activity.

After registration and authorization, credit institutions are subject to registration in the special register for credit institutions, which is kept by the National Bank of Romania as a main body of control and is permanently accessible to the public.

The National Bank of Romania as a main body of banking control, keep in a computerized chronological system, the records of all credit institutions, performing the job of recording all issued authorizations as well as those in force, in the register of credit

\footnotetext{
${ }^{13}$ Article 91 of the Goverment Ordinance no. 99/2006.

${ }^{14}$ Article 3 paragraph (1) in the National Bank of Romania, Reglementation no. 11/2007.
} 
institutions. This register is publicly accessible permanently. The National Bank's Regulation no. $1 / 2007^{15}$ on the register of credit institutions, establishes the register's content as well as the way records on credit institutions are made.

The information contained in the register of credit institutions, according to the regulations, cover the following information: date of registration, the unique trade registration code and the date of registration, the unique tax registration code, the date of the functioning approval, number and date of the authorization received from the National Bank Romania.

The register of credit institutions "is both a means of control for the Central Bank as well as a legal means of advertising the existence and activities of a banking company. In this context, alongside with the things mentioned above, under "Remarks" they will be mentioning all changes in the status of the banks: authorization withdrawal, name change, reorganization, liquidation, bankruptcy, setting up a new management system, financial and operational restructuring for privatization, merger, absorption and other situations"16.

In the case of the National Bank of Romania, the task of dealing with the records of the credit institutions in their special registry belongs to:

$>$ Communication Directorate of the General Secretariat.

$>$ General Directorate for licensing, regulation and prudential supervision of the banks;

After being registred in the register of credit institutions, provided they notify the National Bank of their first operation, credit institutions may start to run the business.

\section{Method for credit institutions registration and authorization}

All credit institutions are subject to the process of registration and licensing by the National Trade Register Office, where they acquire the quality of legal entities, then they get the authorization from the Central Bank of Romania and are recorded into the register of credit institutions.

The National Bank of Romania requires credit institutions to comply with the specific and general founding conditions. After obtaining the unique registration certificate from the National Trade Register Office, credit institutions are subject to the second stage for obtaining the authorization issued by the National Bank of Romania. In the next step, credit institutions shall be registered into the register of credit institutions. Besides keeping track of the authorizations it issues the National Bank of Romania will also supervise the information recorded in the register of the credit institutions.

Each credit institution must have a formal frame business administrator rigorously designed, which include a clear organizational structure with clearly defined lines of responsibility, transparent and consistent, effective processes to identify, manage, monitor and report the risks who is or might be exposed, adequate internal control mechanisms, including administrative and accounting procedures and rigorous remuneration policies and practices that promote and is consistent with healthy and effective risk management. ${ }^{17}$

The register of credit institution in permanently available to the public and it respects regulation no. 1/2007 of the National Bank of Romania. After being recorded in the register, credit institutions will be able to perform the activities they were authorized for.

\section{Types of activities allowed to credit institutions}

Credit institutions operate under the Gouvernment Emergency Ordinance no.99 of 6 December 2006, on credit institutions and capital adequacy, after obtaining authorization from the National Bank of Romania.

The types of activities permited to credit institutions are reflected, according to Ordinance No.99/2006, in:

a) attracting deposits and other repayable funds;

\footnotetext{
${ }^{15}$ National Bank's standards no. 18/2002, on bank registry and the registry of credit co-operative organizations.

${ }^{16}$ Turcu, I., Observations on the legal reglementation of the banking activity", R.D.C. no. 11/1998, page 24.

${ }^{17}$ Petre Lazaroi, Agata Mihaela Popescu, 2012, Study Manual of Law Banking and Currency, PRO Univesitaria, pag. 117.
} 
b) lending money, including: consumer credits, mortgage credits, factoring with or without recourse, financing commercial transactions, including forfeiting;

c) financial leasing;

d) payment operations;

e) issuing and administering means of payment such as: credit cards, travelers checks and others, including electronic money;

f) issuing guarantees and assuming commitments;

g) dealing on its own account and / or on the account of its customers, according to the law, with:

1. instruments of the monetary market, such as: checks, bills, promissory notes, etc;

2. currency;

3. futures and options financial contracts;

4. instruments based on exchange rates and interest rates;

h) securities and other transferable financial instruments; participation into the issuing of securities and other financial instruments;

i) consultancy services related to capital's structure, business strategy and other aspects related to commercial business, services related to mergers and acquisitions and the supply of other advisory services;

j) portfolio management and consultancy;

k) custody and administration of financial instruments;

1) interbank intermediation;

$\mathrm{m})$ services related to providing data and references related to the loan;

n) rental of safe deposit boxes;

o) operations with precious metals and stones;

p) acquisition of shares in other entities;

q) any other activities or services, to the extent that they are part of the financial field of activity, while respecting the special legal provisions governing those activities, if any.

Credit institutions may also carry out other allowed activities, under the authorization granted by the National Bank of Romania, as follows: mandated or commissioned nonfinancial operations, property management operations, customer services, activities that are compatible with the requirements of the credit institution's business and with protecting the interests of depositors. However they are prohibited from engaging in operations like:

- pledging their shares on the account of the bank's debts;

- granting loans secured by shares, other equity securities or bonds issued by the credit institution or another entity in its group;

- attracting deposits or other repayable funds, securities or other valuables from the public, when the credit institution is insolvent."

All the activities of credit institutions can be held to the extent of the authorization granted by the National Bank of Romania, by respecting the effective special and common law.

\section{Bibliography}

Turcu, I., Laws commented upon, Bucharest, C.H. Beck Publishing House, Bucharest, 2013;

Țîrlea, M., R., Business Valuation, Risoprint Publishing House, Cluj-Napoca, 2012;

Petre Lazaroiu, Agata Mihaela Popescu, Study Manual of Law Banking and Currency, PRO Univesitaria, 2012;

Turcu, I., 2006, Banking legislation, Bucharest, C.H. Beck Publishing House, Bucharest, 2006;

Turcu, I., Observations on the legal reglementation of the banking activity, R.D.C., no. 11, page 24, 1998.

*** Emergency Ordinance no. 99 from the 6th of December 2006, On credit institutions and capital adequacy, published in the Official Gazette no. 1027 of the 27th of December 2006;

*** The National Bank of Romania, Reglementation no. 11/2007

*** 2006/48/CE Directive of the Parliament and the European Council.

*** Law no. 31/1990 published in the Official Gazette of Romania, Part I, no. 126-127 on the $17^{\text {th }}$ of November 1990. 